\title{
Equilibrium interest rate and financial transactions in post-Keynesian models. Pointing out some overlooked features
}

\author{
Angel Asensio*
}

\begin{abstract}
The paper argues that beyond the deviations of the long-term interest rate the monetary authority may cause, it is the rate determined by the market conventional expectations that prevails eventually. Lasting influence requires the authority to be capable of changing the market conventional expectations, not only refinancing conditions. The paper also explores the implicit financial transactions behind interest rate determination in post-Keynesian simple macro-models. It points out symmetry between the money and finance markets in equilibrium models. As a consequence of endogenous money, the finance market cannot but clear along with the money market, which sheds light on the rejection of the ,loanable funds theory. In disequilibrium business cycle models, on the other hand, the symmetry is between the financial and goods markets, as in the loanable funds theory.

JEL classifications: EI2, E40, E43, E44, ESI
\end{abstract}

Keywords: endogenous money, equilibrium interest rate, convention, finance, post-Keynesian economics

\section{Introduction}

As pointed out by Rochon (2007: 6), horizontalists and structuralists "agree on the fundamental role of the central bank in setting interest rates and supplying needed liquidity to the banking system«. Hein (2008: 52) also reported that

* $\quad$ CEPN, University Paris I3 - CNRS, France.

Correspondence Address:

Angel Asensio, Centre d'Economie de Paris Nord, UMR CNRS 7234, Université de Paris XIII, 99 avenue Jean-Baptiste Clément, F-93430 Villetaneuse, France, e-mail: asensio.angel@univ-parisız.fr.

Received I May 20IO, accepted in December 2010

(C) INTERVENTION 8 (2), 2OII, 389-404 
»in the long run, it is monetary policies which determine the short-term rate and also the tendency of development of the long-term rate, if the central bank is ready to lend to commercial banks at the given short term rate«.

Yet The General Theory Chapter I5 defines the long-term interest rate as a highly conventional phenomenon`, on which the monetary policy may have more or less influence, but which depends "not only on the current policy of the monetary authority, but also on market expectations concerning its future policy« (Keynes 1936: 202). The paper first points out an aspect of Keynes's argumentation that seems to have been overlooked in the postKeynesian formal approach where the long-term interest rate is determined by the central bank intervention rate (or some derived short-term interbank rate) times an exogenous mark-up. Both positions are examined. It is argued that central banks are not able to control the long-term interest rate effectively in general, though they may control it in favourable circumstances. The exposition however reveals no incompatibility between the postKeynesian approach to endogenous money and Keynes's focus on the market conventional expectations.

The post-Keynesian endogenous money approach does challenge the orthodox view that the rate of interest adjusts so that aggregate saving and investment are equal to each other. Instead, it points out the necessary involvement of money in the financial system and the heavy consequences as regards both the efficiency and the stability of the whole economy. Yet, contrary to stock flow consistent (SFC) models and other models that deal specifically with issues related to the financial system (as in Palley 1996), post-Keynesian simple macromodels do not offer an explicit account of the money/finance transactions behind interest

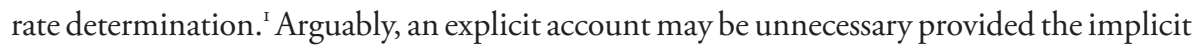
transactions remain coherent. The second objective of this note is to clarify the point formally and propose an accounting framework aimed at dealing explicitly with money/finance transactions in the post-Keynesian simple macro-models.

The paper is organised as follows. Section 2 presents Keynes's argument with respect to the central bank's capacity to control the long-term rate of interest and the way it can be integrated in the post-Keynesian endogenous money approach. In Section 3 a simplified closed economy is considered with one alternative asset to money that seeks to capture all kinds of `risky` (or uncertain) financial assets within a basic framework. The transactions are made explicit so that one can check their mutual consistency and discuss the salient features. Section 4 concludes with respect to the post-Keynesian endogenous money modelling.

I Simple models does not refer to the kind of simplified SFC model proposed in Dos Santo and Zezza (2008), but to the kind of model used for example in Atesoglu and Smithin (2006), Hein (2006), Palley (2007), Setterfield (2009) or Asensio et al. (2009). 


\section{Conventional expectations and the equilibrium interest rate}

Before considering Keynes's argument with respect to the central bank's capacity to control the long-term rate of interest, it will be useful to assess the post-Keynesian horizontalist and structuralist position on the topic.

Fontana (2003, 2004a and 2004b) has offered an interpretation of the structuralists approach to endogenous money that tends to reconcile them with the horizontalist point of view. The argument can be summarised as follows (see Hein 2008 for a detailed exposition); When expectations, liquidity preference and the risk assessment of commercial banks are taken as given (that is, according to Fontana, in a single period analysis $)^{2}$, then the supply curve is horizontal, meaning that the banking system accommodates any additional money demand at the current rate (provided borrowers are judged to be financially safe). If the commercial-banks liquidity problem and the indebtedness of firms therefore increase, then the banking system may wish to raise the loan rates during the subsequent period, which makes the money supply curve shift upwards. Hence both the money quantity and the longterm interest rate have increased eventually, with the result that, if the period of analysis is extended so that the two short periods are considered together, the supply curve is logically positively sloped.

Note that if the banks' liquidity problem and/or the firms indebtedness do not increase in the meantime (as claimed in Hein 2008: 5I), the supply curve need not shift upwards, unless the central bank decides not to accommodate fully the additional demand for reserves. Structuralists, however, emphasise that banks could increase the money supply even if the monetary authority refused to accommodate any increase in the demand for reserves (Palley 2002: 153). That is, in a context where the central bank would not accommodate enough, banks could provide additional liquidity to the markets provided the rate of interest became more attractive. Obviously, the argument does not apply in circumstances where the monetary authority does accommodate any demand for money reserves. But actually it could not apply either when the central bank does not want to accommodate totally, since it supposes that banks could increase the liquidity against the central bank's wishes, which is quite questionable insofar as the central bank can easily deter banks from accommodating too much.

\section{I Have monetary authorities the ultimate say on the convention??}

Hence, horizontalists and structuralists should agree that it is the central bank that finally decides whether an additional money demand will be accommodated completely or not, so that the central bank eventually determines whether the long-term interest rate will increase or not, no matter whether the slope of the supply curve is horizontal at any point in time or

2 As expectations, liquidity preference and risk assessment are subject to sudden shifts in the presence of fundamental uncertainty, the relevant analysis should actually focus on a very short single period or even ra point in timer (see Asensio, forthcoming). 
is positively sloped within some adequate period length. And indeed, most of the sinterest rate rules that have been proposed recently rest on this idea that interest rates are under control (see for example Rochon [2007], Rochon/Setterfield [2007]).

Yet The General Theory Chapter Is defines the long-term interest rate as a highly conventional phenomenon:

"The long-term rate of interest is a highly conventional [...] phenomenon. For its actual value is largely governed by the prevailing view as to what its value is expected to be. Any level of interest which is accepted with sufficient conviction as likely to be durable will be durable; subject, of course, in a changing society to fluctuations for all kinds of reasons round the expected normal.« (Keynes 1936: 203)

This questions the ability of monetary policy to really control the long-term interest rate, especially in the case of interest rate reductions. Accordingly, Lavoie (1999:2) tempers his own judgment that "monetary authorities have the ultimate say on the convention « by pointing out that the spreads between the long-term rates and the overnight rate vary according to the liquidity preference of the commercial banks and the participants in the financial markets:

"As Smithin (1996: 93) puts it, a role for Keynesian liquidity preference can be retained in this scenario, in that liquidity preference considerations may well periodically insert a wedge between those rates of interest which are more or less directly under the central bank control and rates elsewhere." (Lavoie 1999: 2)

Hein therefore admits that " $[\mathrm{t}]$ he central bank's control of the long-term market rate may be limited in the face of changes in expectations and in liquidity preference", but he considers that possibility a temporary phenomenon:

"If sudden increases in liquidity preference occur, they may limit the capacities of the central bank to lower market rates of interest in the short run. [...]. However, these are temporary phenomena« (Hein 2008: 52).

Such a judgment may however look optimistic. As Keynes put forward:

"The short-term rate of interest is easily controlled by the monetary authority [...]. But the long-term rate may be more recalcitrant when once it has fallen to a level which, on the basis of past experience and present expectations of future monetary policy, is considered unsafer by representative opinion. For example, in a country linked to an international gold standard, a rate of interest lower than prevails elsewhere will be viewed with a justifiable lack of confidence; yet a domestic rate of interest dragged up to a parity with the highest rate (highest after allowing for risk) prevailing in any country belonging to the international system may be much higher than is consistent with domestic full employment.« (Keynes 1936: 202-203)

In unfavourable circumstances like the one Keynes put forward, or when central banks are faced with both unemployment and distributive inflationary pressures (or capital markets inflation...), or when the monetary policy "strikes public opinion as being experimental 
in character or easily liable to change (Keynes I936: 203), then central banks may well be unable to greatly decrease the long-term interest rate. The reason is that if authorities started reducing the long-term rate beyond the critical rate, it could be considered sunsafer and could thereby trigger an upward change in the interest rate expectations and a persistent increase in liquidity preference (insofar as expectations remain unchanged). Unfortunately, it is by no means assured that in such circumstances

"the central bank should always be able eventually to drive down the general level of interest rates if they so choose, provided they are sufficiently persistent " (Smithin 2003: 126, quoted in Hein 2008: 53).

Sufficient persistence may fail to change the market expectations if the targeted rate is considered unsafe. As stated in Asensio and Hayes (2009: 76-77), the

"question is whether the authorities are pursuing feasible objectives that have been pragmatically defined in accordance with circumstances, and whether these objectives have been widely understood and accepted. It is a matter of confidence«, rather than persistence. $^{3}$

Hence, whilst the post-Keynesian endogenous money approach is right when it states that banks do deliver the amount of credit money that is demanded at the current interest rate, and whilst it is also correct to say that the long-term rate does not result from a standard market clearing process, ${ }^{4}$ it is not assured nevertheless that the central bank can influence sufficiently the convention so as to set the long-term rate at the level it has decided. It is only if/when, owing to the circumstances and to the consistency of the policy response, the monetary authorities' influence on the market convention is strong enough that they can be said to control effectively the long-term rate of interest.

\subsection{Endogenous money, conventional expectations and the equilibrium rate}

In order to examine the point formally within the standard post-Keynesian framework, consider a situation where an expansionary monetary policy takes place but does not change the conventional expectations since it is judged unsafe (Figure I). As the short-term interest rate $\left(i_{S T}\right)$ decreases, banks may reduce the long-term rate $\left(i_{L T}\right)$ below the conventionally expected rate $\left(i_{\text {conv }}\right)$ so that more money is demanded and delivered.

4 As the conventional expectations that determine the equilibrium interest rate are actually endogenous to the economic system, it is misleading to consider the rate of interest an exogenous variable, although it may be useful to deal with 'given « expectations, conventions and long-term interest rates in formal models. 
Figure I: Temporary long-term interest rate deviation from the conventionally expected rate
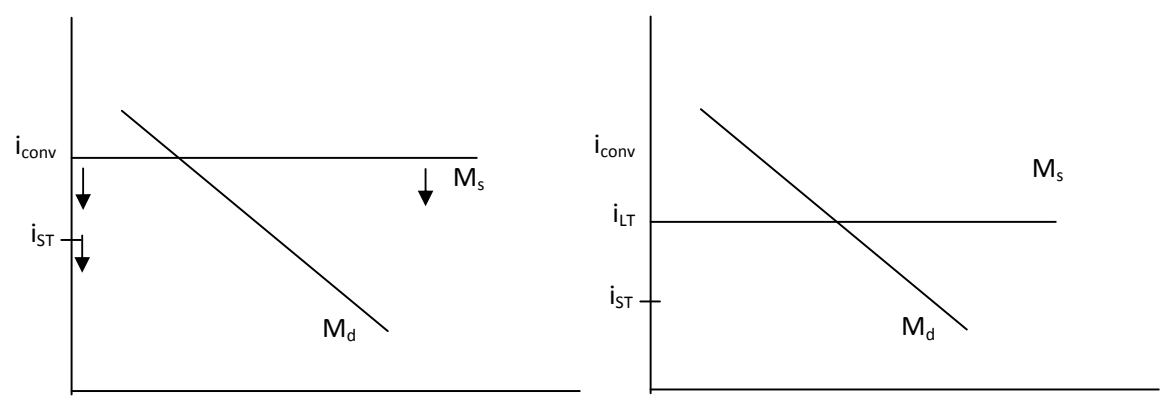

As a future interest rate increase, therefore, is expected, the demand for money shifts to the right (Figure 2). If the banking system then provides the system with the additional creditmoney demanded at the prevailing interest rate, then the money supply fully accommodates the additional demand.

Figure 2: Bearish expectations feed the liquidity preference
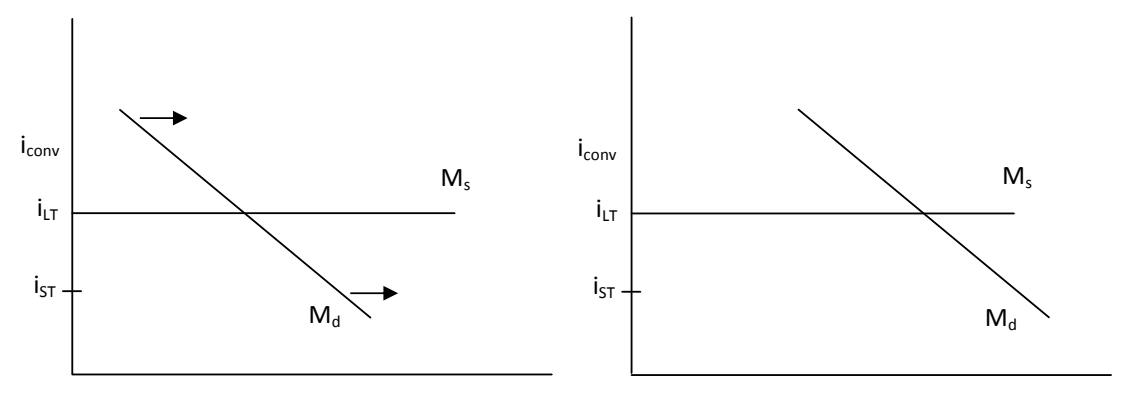

So far, the long-term rate of interest is exogenously determined by the interbank shortterm rate $\left(i_{S T}\right)$, which is assumed to be controlled through central bank decisions, and the commercial banks' mark up (measured by the difference $i_{L T}-i_{S T}$, which in this case is also assumed to be exogenous), so that it stands below the conventionally expected rate. But this could hardly continue for it would suppose that banks accept creating more money at the prevailing rate instead of taking advantage of a situation where borrowers may be willing to pay a higher interest rate than previously. Indeed, as long as the actual rate remains below the conventional level, bearish expectations in the financial markets continue to feed the liquidity preference and make money scarcer, so that the long-term interest rate eventually goes back to the conventional rate. No matter the quantity of money supplied by the banking system, in the absence of confidence as to whether the central bank is able to drive the convention, 
the market may be capable of maintaining the scarcity of money and the related long-term interest rate. ${ }^{5}$ All the more since the central bank is expected to resist pumping more reserves if/when it becomes necessary to accept collaterals of lower and lower quality.

In Figure 3 banks increase the rate of the additional credit-money they deliver, which makes the supply curve shift upwards, while the central bank may or may not increase the short-term rate, or may increase it but not to the same extent. ${ }^{6}$

\section{Figure 3: The long-term interest rate eventually goes back to the conventional rate}
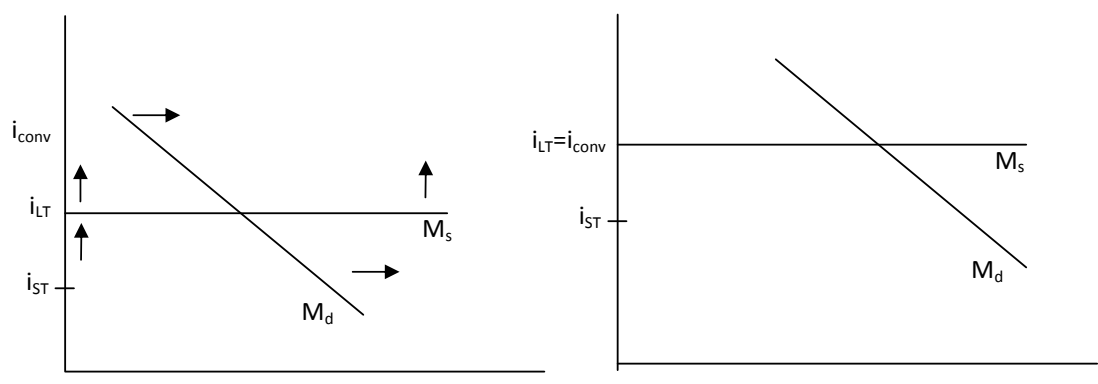

As claimed by Keynes, it turns out that the rate of interest is governed by market convention, which appears to operate as an attractor for the market rate. In this sense, despite the market conventional views not following any predictable law independently of the context, so that there is no spontaneous tendency towards any predetermined 'naturak rate, and despite the fact that the long-term interest rate accordingly has to be taken as given (unless the formation of the market convention can be modelled), it is nevertheless an endogenous (shifting) equilibrium value. Arguably the central bank is capable of disconnecting the long-term interest rate from the conventional rate for a time. As suggested in the above citation from The General Theory, the interest rate at any time is not necessarily equal to the conventionally expected rate and even "may fluctuate for decades about a level which is chronically too high for full employment [...] «(Keynes 1936: 204). But it is much more uncertain of influencing the market convention, and thereby having a durable influence on the long-term interest rate. This requires something more than setting the banks refinancing conditions and shortterm interest rates. It requires the authority objective being convincing enough as to curb the market expectations, which does not always depend solely on the goodwill of authorities. ${ }^{7}$

$5 \quad$ "Thus a monetary policy which strikes public opinion as being experimental in character or easily liable to change may fail in its objective of greatly reducing the long-term rate of interest, because M2 may tend to increase almost without limit in response to a reduction of $r$ below a certain figure." (Keynes 1936: 203)

6 Hence the banks mark-up does not necessarily increase during the process.

7 See Asensio (2009: 13-I4) for further discussion. 
The conclusion above also holds if non-bank loans are introduced into the discussion, as suggested in Palley's claim for an sendogenous financer theory (Palley I996: ch. 8). Let us consider again the case where the monetary base is increased as a result of a cheaper refinancing policy, and, as a matter of consequence, banks start reducing the long-term rates so that the demand for credit is stimulated. If, at the same time, the liquidity preference increases because of a loss of confidence or because a future increase of interest rates is expected, bonds and other non-bank loan rates tend to rise in order to compensate for the increasing liquidity preference (and banks of course are able to sell more credit without reducing their interest rates substantially). Keynes accordingly wrote that even if

"the monetary authority were prepared to deal both ways on specified terms in debts of all maturities, and even more so if it were prepared to deal in debts of varying degree of risk", there would be »limitations on the ability of the monetary authority to establish any given complex of rates of interest for debts of different terms and risk" (Keynes I936: 205-207).

See Keynes (1936: 207-208) for a detailed discussion of these limitations.

\section{The financial side of endogenous money in post-Keynesian simple macro-models}

,Endogenous financer means basically that all the investments that are judged to be safe do find the required funds, either by means of internal finance, or by means of bank or nonbank financing. Actually, this feature is guaranteed in post-Keynesian theory through the adjustment of the output level, which increases (decreases) so as to adjust the global amount of saving to the level of investment. ${ }^{8}$ It is obviously present in post-Keynesian models, although sometimes little (or no) emphasis is placed on the issue. The horizontalist approach for example usually emphasises the role of the banking system, but of course this does not imply that other sources of financing are ignored.

\section{I The basic framework}

In order to show the type of money/finance transactions that remain implicit in numerous post-Keynesian macro-models and to discuss some related issues, a basic closed economy is considered in which a financial asset is introduced explicitly. For the sake of convenience

8 In Palley's endogenous finance model "the interest rate also increases as higher nominal incomes raise the demand for loans which places upward pressures on interest rates (Palley 1996: 132). The argument of the previous section here suggests that, if authorities want to accommodate, endogenous finance does not need higher interest rates (given the market conventional expectations), and if authorities do not want to accommodate totally, then financial intermediaries (banks and non-banks) can hardly oppose. 
this asset is generically labelled `security` $(B)$, but it aims at representing all types of contract by which somebody transfers provisionally a certain amount of resources to somebody else in exchange for revenues or dividends that will be generically labelled interest $<~(i)$. As the financial institutions cannot be detailed in such a basic framework, the central bank is assimilated to the public sector as the provider of money, while banks are supposed to circulate the money supplied among firms and households, in exchange for some private debt-certificates that are part of the ssecuritiesı category. Also, banks and non-bank financial institutions are supposed to put suppliers and demanders of securities together, so that they can make transactions.

The household resources, namely wages $(w N)$ and financial revenues $\left(i B_{0}\right)$, allow them to buy consumption goods $(C)$, to pay fiscal taxes $\left(T^{h}\right)$ and, as regards saving, to hold more money $\left(\Delta M^{h}\right)$ and/or buy new securities $(\Delta B)$. The firms output and borrowed resources $\left(Y, \Delta B^{f}\right)$ allow them to pay the wages, invest $(I)$, pay fiscal taxes $\left(T^{f}\right)$, pay interest $\left(i B_{0}^{f}\right)$, and hold some additional cash $\left(\Delta M^{f}\right)$. The public sector resources result from fiscal taxes and from increases in the stocks of money $(\Delta M)$ and public debt $\left(\Delta B^{g}\right)$; they allow the financing of current expenditures $(G)$ and the paying of interest $\left(i B_{0}^{g}\right)$. For the sake of simplicity, it is assumed that public expenditures concern consumption (not investment) goods.

Table I (on the next page) shows the resources and expenditures with respect to the type of economic agent. For the sake of subsequent developments, a ss or a $>d<$ in lower script identifies whether the agent is a supplier or a sdemander

The above framework is an accounting system. It is not a model of the economy and does not presuppose any specific way for the payment of transactions. Hence the way, for example, the goods market is accounted for is not to be understood as a market of goods against goods, or against money or anything else, but simply as a market where supply and demand may potentially differ or not. It is the aim of the theory, not of the accounting framework, to specify the way the economy adjusts to certain positions and how transactions are paid for. ${ }^{9}$ The accounting system simply aims at representing consistently any possible situation, which includes potentially cleared situations as well as excess supply or excess demand situations, though of course suppliers and/or demanders in these cases must suffer from some rationing. Hence, whatever the market considered is, in Table I the related sum of amounts with a ss in lower script is necessarily equal to the related sum of amounts with $\mathrm{a}>\mathrm{d}$ < in lower script, but this does not necessarily mean that the market clears, since some agents may have been rationed when doing the transactions.

Although the economy comprises four macro-markets (goods, labour, money and securities), it is sufficient to represent three of them because of the aggregate budget constraint. Indeed, in terms of the planned ${ }^{\mathrm{IO}}$ or desired transactions (total planned resources-total planned expenditures $=0$ ), the aggregate budget constraint yields:

9 We consider below a standard post-Keynesian monetary production economy, where the equilibrium transactions that involve the markets for goods, securities and labour are paid for in money, thereby putting the money market at the core of the economic system.

IO Planned resources/expenditures differ from the realised ones in case of rationing. 

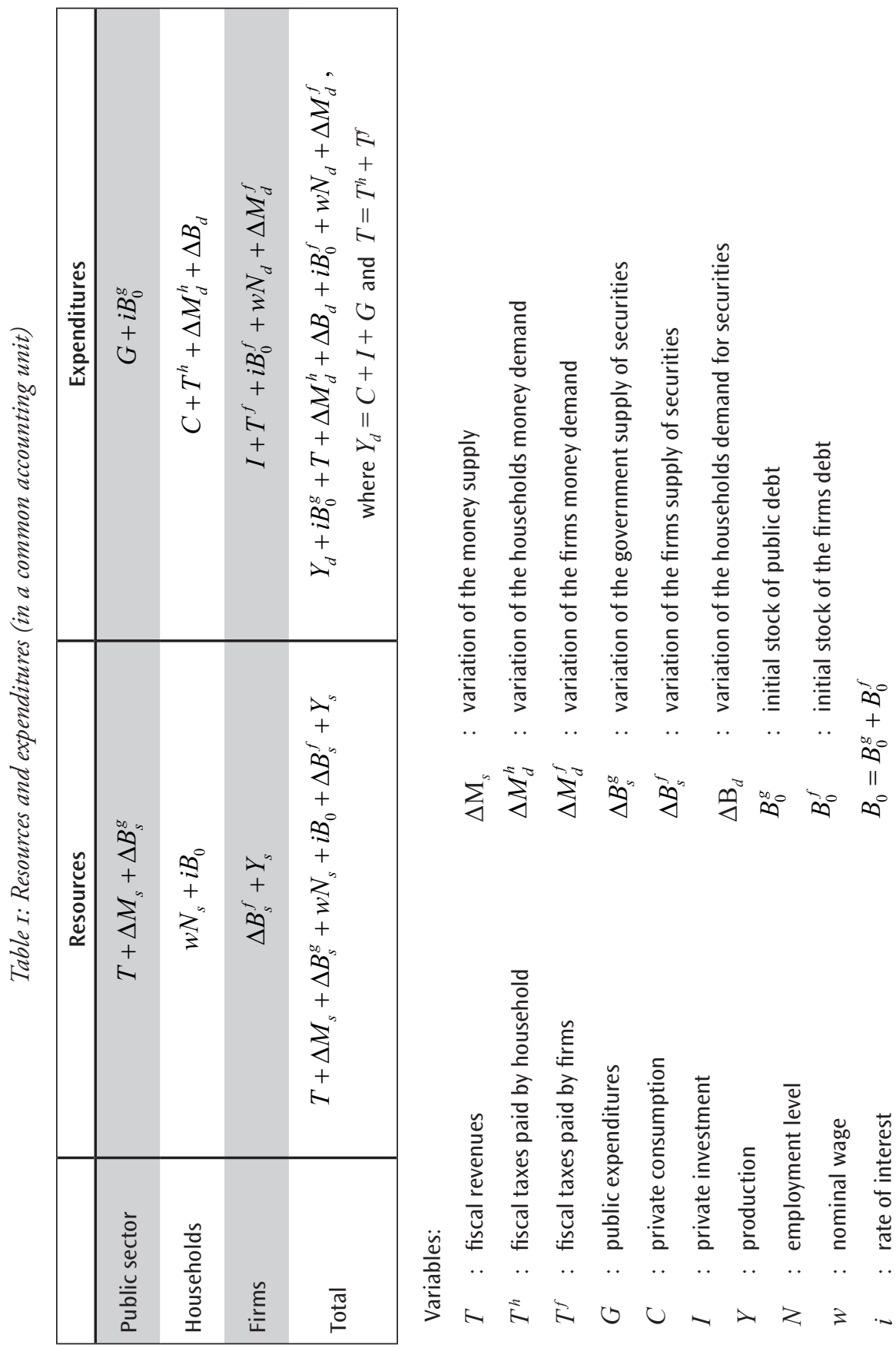


$$
\left(\Delta M_{s}-\Delta M_{d}^{h}-\Delta M_{d}^{f}\right)+w\left(N_{s}-N_{d}\right)+\left(\Delta B_{s}^{f}+\Delta B_{s}^{g}-\Delta B_{d}\right)+\left(Y_{s}-Y_{d}\right)=0,
$$

which demonstrates that the situation of any market can be deduced from the situation in the three other markets. Standard models usually formalise the goods market, the labour market and the money market. Insofar as in post-Keynesian economics firms have to adapt their production and hiring decisions to effective demand, the workers supply of labour is rationed by the firms $\left(N_{s}=N_{d}\right.$, for any $N_{d}$ decided by the firms so as to adjust the supply of goods to the effective demand). ${ }^{\text {II }}$ Therefore, replacing $N_{s}$ by $N_{d}$ in equation I, and given that this supposes the equality $Y_{s}=Y_{d}$, we get:

$$
\left(\Delta M_{s}-\Delta M_{d}^{h}-\Delta M_{d}^{f}\right)+\left(\Delta B_{s}^{f}+\Delta B_{s}^{g}-\Delta B_{d}\right)=0
$$

for any $N_{d} \leq N_{f e}$ decided by the firms so as to adjust the supply of goods to the effective demand. $N_{f e}$ denotes full employment.

This expresses a strict symmetry between the money market and the securities market. As a matter of accounting coherence, the money market does involve an exact counterpart in the securities market. A direct implication for the post-Keynesian theory of endogenous money is that, if the money supply endogenously sticks to the money demand so that $\Delta M_{s}=\Delta M_{d}^{h}+\Delta M_{d}^{f}$, the market for securities cannot but clear too (for any $N_{d} \leq N_{f e}$ decided by the firms so as to adjust the supply of goods to the demand). ${ }^{\text {I2 }}$

\subsection{The financial side of endogenous money}

Although standard models only focus on the above three markets, an explicit account of the financial transactions may prove to be useful in revealing some hidden features of the model. Let us examine the demand for securities first. As money is a hedge against uncertainty, savers may wish to hold a proportion of their savings in money instead of securities, depending on whether the rate of interest compensates for the liquidity preference. They sell or buy securities according to the amount of money they want to hold. Assuming, for the sake of simplicity, a closed economy where at the macro level the firms and the public sector are borrowers while the households are savers, the demand for securities increases over the period considered by the total amount of the households saving minus the households money demand:

II For the sake of simplicity we ignore the possible difference between the realised aggregate demand and the expected future demand that determines the current production of firms. Hence $Y_{d}$ stands for both the effective and realised demand in Table I. This is the approximation Keynes (1936: 46-5I) advocated in chapter 5 of The General Theory.

I2 Equilibrium therefore, in accordance with the post-Keynesian theory, is a situation where money supply sticks to demand, where the production of goods sticks to effective demand, the supply of labour is rationed by (hence equal to) the demand below full employment (or possibly at full employment provided the effective demand is strong enough), and where, as a result of the aggregate budget constraint, the supply and demand for securities are equal. Of course, there would be much more to discuss about the notion of equilibrium in post-Keynesian theory, but it is out of the present paper's purpose (see Asensio, forthcoming, for an assessment of the status of equilibrium in the General Theory). 


$$
\Delta B_{d}=S^{h}-\Delta M_{d}^{h}
$$

On the supply side, let $S^{f}$ be the firms own savings, as defined by their current account ${ }^{\mathrm{I} 3}$ :

$$
S^{f}=Y_{s}-w N_{d}-i B_{0}^{f}-T^{f}
$$

From the firms' budget constraint we get:

$$
Y_{s}-w N_{d}-i B_{0}^{f}-T^{f}=\Delta M_{d}^{f}-\Delta B_{s}^{f}+I .
$$

Hence:

$$
S^{f}=\Delta M_{d}^{f}-\Delta B_{s}^{f}+I \Rightarrow \Delta B_{s}^{f}=I+\Delta M_{d}^{f}-S^{f} .
$$

That is, the firms provide securities to the extent that their own saving $\left(S^{f}\right)$ is not enough to pay for their productive investments, given the variation in their money holdings.

As regards the government, assuming a budget deficit for the sake of simplicity, its (negative) saving is given, by definition, by its current account (deficit):

$$
S^{g}=T-G-i B_{0}^{g} \text {. }
$$

From the government budget constraint we get:

$$
\Delta B_{s}^{g}+\Delta M_{s}=G+i B_{0}^{g}-T \Rightarrow \Delta B_{s}^{g}=G+i B_{0}^{g}-T-\Delta M_{s} .
$$

So that the government provides securities to finance the deficit share that is not paid with additional money supply.

Aggregating $\Delta B_{s}^{f}$ and $\Delta B_{s}^{g}$, we get the total supply of securities $\left(\Delta \mathrm{B}_{s}\right)$ :

$$
\Delta B_{s}=I+\Delta M_{d}^{f}-S^{f}+G+i B_{0}^{g}-T-\Delta M_{s} .
$$

In this demand/supply for finance framework, ${ }^{14}$ the above mentioned money/finance symmetry can be derived as a result of the global saving/investment equality: $S^{h}+S^{f}+S^{g}=I$, from which derives the equality between the net private saving and the public deficit:

$$
S^{h}(Y)+S^{f}(Y)-I=G+i B_{0}^{g}-T .
$$

Hence, replacing the sum $\left(I-S^{f}+G+i B_{0}^{g}\right)$ in equation (3) by $S^{h}$ yields:

$$
\Delta B_{s}=S^{h}-\Delta M_{s}+\Delta M_{d}^{f} .
$$

Then given equation (1), one can see that:

$$
\Delta B_{d}-\Delta B_{s}=\Delta M_{s}-\Delta M_{d}, \text { where } \Delta M_{d}=\Delta M_{d}^{h}+\Delta M_{d}^{f} .
$$

I3 Remember that the current account does not comprise capital $(I)$, money $(\Delta M)$ nor finance $(\Delta B)$ operations. The firms' saving is a measure of their profit.

I4 Suppliers of securities actually demand finance, while demand for securities amounts to supplying finance. 
and

$$
\Delta M_{s}=\Delta M_{d} \Leftrightarrow \Delta B_{d}=\Delta B_{s}
$$

The meaning of this money/finance symmetry may be illustrated by means of an example. Note first that, in accordance with equation (5), an excess money demand would suppose the demand for securities decreases below the supply level as a counterpart of the additional money demand. But this is a virtual case since, as stipulated in the endogenous money approach, if the banking system does accommodate the money demand at the previous rate, then the additional money supply satisfies the additional demand altogether without need for individuals to reduce the demand for securities below its previous equilibrium level. Hence while symmetric disequilibria may virtually be thought of where excess money demand (supply) and excess securities supply (demand) compensate for each other, the system actually delivers cleared money and securities markets.

Since the rate of interest and the level of output determine the money demand and, thereby, the money quantity, it happens, according to the mentioned symmetry, that the rate of interest and the production of goods are the key variables that adjust the supply and demand for securities as well. But the clearing of the securities market does not preclude the possibility of insufficient effective demand and unemployment in post-Keynesian theory, while it does in the Classical tradition. Under competitive conditions, the Classical sloanable funds theory`stipulates that the long-term rate of interest does adjust so that the demand and supply for securities are equal to each other, whatever the equilibrium level of (full)employment the labour market delivers, thereby reaching the equilibrium level that assures that no shortage in aggregate demand for goods can arise (the so-called 'Say's lawı). Accordingly, an insufficient aggregate demand of goods, or, equivalently, an excess of fullemployment saving over investment could not be a stable situation, for it would trigger a decrease in the rate of interest, thereby clearing both the market for goods and the market for saving simultaneously. But in the presence of uncertainty, the long-term interest rate decrease caused by a depressed aggregate demand, and the real balance effect as well, may meet some obstacles. ${ }^{\text {Is }}$ First, if the money supply decreases endogenously along with the demand for money, the rate of interest does not decrease. Secondly, the depressive forces are likely to harm the state of confidence in such a way that people want to increase the share of money in their portfolio, which inhibits both the Keynes and Pigou effects, even if the authorities were prepared to let the interest rate decrease by means of a weaker decrease in the money supply.

Why can the mainstream theory not consider these obstacles? The answer is clearly because uncertainty is never considered as anything but ‘riskı, so that when a depression arises people do not want to increase the share of money as long as the depression is considered to be 'white noiser. Say's law only holds under the restrictive condition that the depression is

I5 Even if the rate decreases, the worsening business climate can deter investments (as marginal efficiency of capital schedule goes down) in such a way that unemployment does not decrease (and may even increase, as Keynes (1936: 263) put forward in chapter I9 of The General Theory. 
considered a temporary deviation without long-run impact, which postulates some regulatory forces that operate in the long run so as to anchor the economy in a predetermined `naturak position. In the face of true uncertainty, on the other hand, the speculative demand for money tends to be too high and the inducement to invest too low, which inhibits Say's law even in competitive markets. In the post-Keynesian theory, therefore, global saving does adjust to global investment through the production (and employment) adjustment to effective demand. Hence, the critical point is not whether the rate of interest is involved in the market for sloanable funds or not. Of course it does (though not in the way stipulated in the sloanable funds theory of interest). The point is that, because of uncertainty and liquidity preference, the conventional rate of interest at which borrowers can get funds to finance their investments may be too high for full employment. ${ }^{16}$

Notice that if one seeks to introduce endogenous money within models of business cycles that explore disequilibrium issues, as in Kalecki (1939) and Kaldor (1940), ${ }^{17}$ a noticeable difference appears. Insofar as the global saving and the global investment are allowed to differ from each other in those models, they deal with situations of disequilibrium in the goods market. Hence, if the money market clears owing to endogenous money supply and if the labour market is rationed in the way mentioned above, then identity (1) leads to:

$$
\left(\Delta B_{s}^{f}+\Delta B_{s}^{g}-\Delta B_{d}\right)+\left(Y_{s}-Y_{d}\right)=0 .
$$

In this case the money/finance symmetry disappears in such a way that an excess supply of goods goes along with an excess demand of securities (supply of funds), as in the sloanable funds theory ‘. It is beyond the remit of the present paper to discuss the issue, but it is worth noting that the explicit account of the financial side here reveals underlying aspects that deserve discussion.

\section{Conclusion}

Two important features of the post-Keynesian literature on endogenous money have been examined in the present paper. The first one is about the long-term interest rate determination. The argument according to which monetary authorities can control this rate effectively has been disputed in accordance with Keynes's position that it is determined by the markets' conventional views about the future. The discussion leads to the result that, except in favourable circumstances, authorities cannot be sure of having effective control. Beyond the temporary deviations of the market rate, for monetary policy to have lasting influence requires the authority being capable of changing the market conventional expectations. Sometimes the central bank may meet this condition by simply changing the short-term rates and refinancing conditions, but sometimes something more is necessary which relies

I6 As Keynes (1936) pointed out in The General Theory, chapter 19, wage decreases are likely to depress further the effective demand, so that they could hardly replace the sloanable funds theory` mechanism excepted in peculiar circumstances.

I7 See also Semmler (1986) and Assous (2010) for a recent appraisal. 
on the confidence the monetary policy imposes on the public and markets opinion. These considerations have been obtained within the usual formal apparatus of the post-Keynesian approach to endogenous money, which thereby reveals no incompatibility with Keynes's focus on the conventional nature of the rate of interest.

The second feature is about the implicit financial transactions lying behind the determination of the rate of interest in post-Keynesian simple macro-models. These models are used to focus explicitly on three macro-markets only in a closed system (goods, labour and money), since the aggregate budget constraint allows the sparing of the explicit representation of one out of the four standard macro-markets. But as an explicit account of the financial transactions may reveal some hidden features usefully, the paper has examined the issue formally. The proposed synthetic framework reveals the symmetry between the money and the finance market when the supply of goods adjusts to the aggregate demand below full employment. A direct implication of endogenous money is that the market for finance cannot but clear together with the money market in this case. Hence, as regards the market for sloanable funds`, the critical point is not whether or not the rate of interest is involved; the point is that, because of uncertainty and liquidity preference, the rate of interest at which borrowers can get funds to finance their investments may be too high for full employment. As regards business cycle models that explore investment/saving disequilibrium issues, the explicit account of the financial side reveals underlying aspects that deserve further discussion. Notably, if the money market clears owing to endogenous money supply, then the money/ finance symmetry is replaced with one between the financial market and the market for goods, as in the sloanable funds theory`.

\section{References}

Asensio, A. (forthcoming): On Keynes's seminal innovation and related essential features: Revisiting the notion of equilibrium in The General Theory, in: Cate, T. (ed.), Keynes' General Theory: Seventy-five years Later, Cheltenham: Edward Elgar, $201 \mathrm{.}$

Asensio, A. (2009): Between the cup and the lip - On Post Keynesian interest rate rules and longterm interest rates management, paper presented at the IEPI-Laurentian U. conference: The political economy of central banking, Toronto, May. IEPI WP-2009-I4.

Asensio, A., Hayes, M. (2009): Post Keynesian alternative to inflation targeting, in: Intervention. European Journal of Economics and Economic Policies, 6(I), 2009, 67-8I.

Asensio, A., Charles, S., Lang, D. (2009): Post-Keynesian modeling: Where are we, and where are we going to?, paper presented at the conference: The recent developments in Post Keynesian modelling, CEPN, University Paris I3, November.

Assous, M. (2010): Income distribution and the trade cycle in the 'years of high theory`(1926-1939), paper presented at the $3^{\text {th }}$ International Conference of the Charles Gide Association for the Study of Economic Thought: Institutions in Economic Thought, Paris, 2010.

Atesoglu, H.S., Smithin, J. (2006): Inflation targeting in a simple macroeconomic model, in: Journal of Post Keynesian Economics, 28(4), 673-688. 
Dos Santos, C. H., Zezza, G. (2008): A simplified, benchmark, stock flow consistent postKeynesian growth model, in: Metroeconomica, 59(3), 44I-478.

Fontana, G. (2003): Post Keynesian approaches to endogenous money: A time framework explanation, in: Review of Political Economy, I5, 29I-3I4.

Fontana, G. (2004a): Rethinking endogenous money: A constructive interpretation of the debates between horizontalists and structuralists, in: Metroeconomica, 55, 367-85.

Fontana, G. (2004b): Hicks on monetary theory and history: Money as endogenous money, in: Cambridge Journal of Economics, 28, 73-88.

Fontana, G., Setterfield, M. (2009): A simple (and teachable) macroeconomic model with endogenous money, in: Fontana, G., Setterfield, M. (eds.), Macroeconomic theory and macroeconomic pedagogy, Basingstoke: Palgrave Macmillan, I44-i68.

Hein, E. (2006): Wage bargaining and monetary policy in a Kaleckian monetary distribution and growth model: Trying to make sense of the NAIRU, in: Intervention. European Journal of Economics and Economic Policies, 3(2), 305-329.

Hein, E. (2008): Money, Distribution Conflict and Capital Accumulation, Basingsstoke: Palgrave MacMillan.

Kaldor, N. (1940): A model of the trade cycle, in: Economic Journal, 50, 78-92.

Kalecki M. (1939): Essays in the Theory of Economic Fluctuations, London: Allen and Unwin.

Keynes, J.M. (1936): The General Theory of Employment, Interest and Money, London: Macmillan.

Palley, T.I. (1996): Post Keynesian Economics: Debt, Distribution, and the Macro Economy, London: Palgrave Macmillan.

Palley, T.I. (2002): Endogenous money: What it is and why it matters, in: Metroeconomica, $53(2), \mathrm{I} 52-\mathrm{I} 8 \mathrm{O}$.

Palley, T.I. (2007): Macroeconomics and monetary policy: Competing theoretical frameworks, in: Journal of Post Keynesian Economics, 30, 6I-78.

Rochon, L.P. (2007): The state of Post Keynesian interest rate policy: Where are we and where are we going?, in: Journal of Post Keynesian Economics, 30(I), 3-II.

Rochon, L.P., Setterfield, M. (2007): Interest rates, income distribution, and monetary policy dominance: Post Keynesians and the "fair rate» of interest, in: Journal of Post Keynesian Economics, 30(I), I3-42.

Semmler, W. (I986): On non-linear theories of the trade cycle and the persistence of business cycles, in: Mathematical Social Sciences, II, 47-75.

Setterfield, M. (2009): Macroeconomics without the LM curve: An alternative view, in: Cambridge Journal of Economics, 33(2), 273-93.

Smithin, J. (1996): Macroeconomic Policy and the Future of Capitalism: The Revenge of the Rentiers and the Threat to Prosperity, Aldershot: Edward Elgar.

Smithin, J. (2003): Controversies in Monetary Economics, revised edition, Cheltenham: Edward Elgar. 